JP3I (Jurnal Pengukuran Psikologi dan Pendidikan Indonesia), 8(2), 2019, 105-II7

D0l: http://dx.doi.org/I0.15408/jp3i.v8i2.13292

http://journal.uinjkt.ac.id/index.php/jp3i

\title{
Analisis Model Fit Butir Soal pada Instrumen Penilaian Kognitif IImu Pendidikan Alam (IPA) Sekolah Menengah Pertama
}

\author{
Dyah Febria Wardhani, Suratno, Aminuddin Prahatama Putra \\ Universitas Lambung Mangkurat, Indonesia \\ dyah2302@gmail.com
}

\begin{abstract}
The importance of quality cognitive assessment instruments so that evaluations conducted really measure what the instrument should measure. This study aims to describe the number of items that are fit in the cognitive assessment instruments of junior high school science subjects that have been developed. This descriptive research was conducted in 7 SMP / MTs in Banjar District. Data in the form of a comparison of questions that are not fit. The results showed that items that were fit on the cognitive assessment instruments developed were $59.80 \%$ (2013 curriculum), I2.74\% (KTSP), and 78.43\% (2013 Impact Curriculum).
\end{abstract}

Keywords: Item; Rasch Model; Science

\begin{abstract}
Abstrak
Pentingnya instrumen penilaian kognitif yang berkualitas agar evaluasi yang dilakukan benar-benar mengukur apa yang seharusnya diukur oleh instrumen tersebut. Penelitian ini bertujuan untuk mendeskripsikan jumlah butir soal yang fit pada pengembangan instrumen penilaian kognitif mata pelajaran IPA SMP. Penelitian deskriptif ini dilakukan pada 7 SMP/MTs Kabupaten Banjar. Data berupa perbandingan soal yang tidak fit menurut kurikulum yang diimplementasikan. Hasil penelitian menunjukkan bahwa butir soal yang fit pada instrumen penilaian kognitif yang dikembangkan adalah 59,80\% (kurikulum 2013), I2,74\% (KTSP), dan 78,43\% (Kurikulum Imbas 20I3).
\end{abstract}

Kata kunci: Model Fit; Butir Soal,Penilaian; IPA 


\section{Pendahuluan}

Hasil belajar kognitif penting bagi siswa dalam mempelajari berbagai mata pelajaran termasuk materi Biologi yang merupakan salah satu mata pelajaran di SMP yang terintegrasi dalam IPA (Wardhani, 2017). Pada aspek biologi, IPA mengkaji berbagai persoalan yang terkait dengan fenomena yang terjadi pada makhluk hidup dan interaksinya dengan berbagai faktor lingkungan (Mamu, 20I4).

Standar penilaian pendidikan menyebutkan bahwa instrumen penilaian yang digunakan harus memenuhi persyaratan substansi, konstruksi, bahasa, dan memiliki bukti validitas empirik serta menghasilkan skor yang dapat dibandingkan antar sekolah, antar daerah dan antar nasional (Mendiknas, 2007). Pengembangan instrumen dengan mengikuti langkah-langkah yangs sitematis dapat memberikan hasil yang optimal dengan sedikitnya item yang tidak fit dengan Rasch Model untuk data dikotomus (Mardapi, 20I I).

Aplikasi Rasch Model dalam pengembangan tes bisa menjadi alat yang kinerjanya sangat baik dalam evaluasi (Sukor, 2013). Analisis Rasch adalah salah satu jenis model logistik I parameter yang mengubah data ordinal menjadi data interval untuk mengatasi ketergantungan sampel dan cocok untuk data dikotomus (Golia, 2010 dan Rasch, 1960 dalam Chiang, 2015). Analisis dengan model ini, dapat dilakukan menggunakan program Bigsteps (Ariffin, 2010; Sukor, 2013; Hidayati, 2013). Kualitas butir soal telah diketahui melalui hasil analisis menggunakan Bigsteps yang mengkategorikan butir soal dalam tiga kategori sesuai kecocokan butir soal dengan model rasch dan tingkat kesukarannya (Prilantari, 2007).

\section{Metode}

Penelitian yang dilakukan adalah penelitian deskriptif, melibatkan SMP/MTs yang ada di Kabupaten Banjar sebanyak 7 sekolah yang dipilih sesuai cluster random sampling.. Jenis data yang diperoleh dalam penelitian ini adalah data butir soal yang fit sesuai model rasch. Instrumen pengumpulan data yang digunakan dalam penelitian ini adalah output Program Bigsteps. Data dianalisis secara deskriptif melalui perbandingan butir yang tidak fit pada tiap sekolah, jenis kurikulum, dan kelompok akreditasi.

\section{Hasil dan Pembahasan}

Butir soal yang fit pada instrumen penilaian kognitif mata pelajaran IPA hasil pengembangan dapat dilihat pada Tabel I.

Tabel I. Ringkasan Hasil Analisis Butir Soal Fit

\begin{tabular}{|c|c|c|c|}
\hline No & $\begin{array}{l}\text { Instrumen } \\
\text { Penilaian } \\
\text { Kognitif }\end{array}$ & Kelas & Nomor Butir Soal \\
\hline \multirow[t]{3}{*}{ I. } & Kurikulum & VII & $\mathrm{I}, 2,4,5,6,7,8, \mathrm{I} 0, \mathrm{II}, \mathrm{I} 2, \mathrm{I} 3, \mathrm{I} 4, \mathrm{I} 6, \mathrm{I} 9,20,2 \mathrm{I}, 22,24,25,27,30$ \\
\hline & 2013 & VIII & $\begin{array}{l}\text { I, 2, 4, 5, 6, 7, 9, II, I2, I3, I6, I7, I9, 22, 23, 24, 26, 30, 32, 34, 35, 37, 38, } \\
40,44,45,47,49,50\end{array}$ \\
\hline & & IX & $\mathrm{I}, 2,5,6,9,10,13,14,16,17,2 \mathrm{I}$ \\
\hline \multirow[t]{3}{*}{2.} & KTSP & VII & $3,4,8,19,21,22$ \\
\hline & & VIII & $\mathrm{I} 3, \mathrm{I} 4, \mathrm{I} 8,34$ \\
\hline & & IX & $8,17, I 8$ \\
\hline \multirow[t]{3}{*}{3.} & Imbas & VII & $\begin{array}{l}\mathrm{I}, 2,3,4,5,6,7,9, \mathrm{I} 0, \mathrm{I} 2, \mathrm{I} 3, \mathrm{I} 4, \mathrm{I} \text {, I8, I9, 20, 2I, 22, 23, 24, 25, 27, 28, } \\
29,30\end{array}$ \\
\hline & & VIII & $\begin{array}{l}\mathrm{I}, 2,3,4,5,8,9 \text {, II, I2, I3, I4, I5, I6, I7, I9, 2I, 22, 23, 24, 25, 26, 27, 28, } \\
30\end{array}$ \\
\hline & & IX & $\mathrm{I}, 3,4,7,8, \mathrm{I} 0, \mathrm{II}, \mathrm{I} 3, \mathrm{I} 4, \mathrm{I} 5, \mathrm{I} 6, \mathrm{I} 7, \mathrm{I} 8, \mathrm{I} 9,23,24,25,26,27,28,30$ \\
\hline
\end{tabular}

Sumber : Hasil Olah Data 
Secara umum, tabel I menunjukkan bahwa soal yang fit pada instrumen penilaian kognitif kurikulum 2013 sebanyak 61 butir atau 59,80\%, instrumen penilaian kognitif KTSP sebanyak I3 butir atau I2,74\%, dan instrumen penilaian kognitif kurikulum imbas 2013 sebanyak 80 buah atau 78,43\%. Item fit dari instrumen penilaian kognitif dari ketiganya belum mencapai 100\%.

\section{Butir Soal yang Fit pada Instrumen Penilaian Kognitif Mata Pelajaran IPA SMP yang mengimplementasikan Kurikulum 2013}

Butir soal yang fit (kelas VII) terdiri atas soal 5 soal yang mudah, 12 soal yang sedang, dan 4 soal yang sulit. Ditemukan soal yang berprilaku tidak konsisten yaitu soal nomor 2, 20, dan 24. Cuplikan soal yang mudah dapat dilihat pada gambar I.

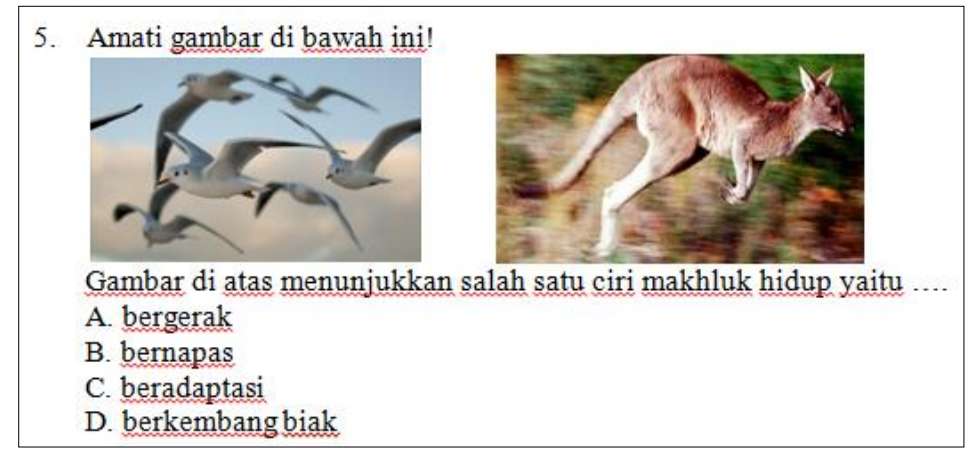

Gambar I. Cuplikan Soal Kategori Mudah pada Instrumen Penilaian Kognitif Kelas VII Kurikulum 2013 (Sumber: Hasil Olah Data)

Soal pada gambar I memiliki nilai item measure sebesar -2,08 di SMPN I Martapura, -2,76 di SMPN I Gambut, dan -2,I6 di sekolah-sekolah berkurikulum 2013 dan akreditasi A (Kurikulum 2013). Soal tersebut merupakan soal yang mudah dan berkualitas cukup baik (Anggraini \& Suyata, 2014 dan Prilantari 2007). Cuplikan soal yang sedang dapat dilihat pada Gambar 2

7. Bagian sel yang berfungsi mengatur semua kegiatan sel adalah ....
A. plastida
B. nukleus
C. nukleolus
D. mitokondria

Gambar 2 Soal Kategori Sedang pada Instrumen Penilaian Kognitif Kelas VII Kurikulum 2013 (Sumber: Hasil Olah Data)

Soal pada gambar 2 memiliki nilai item measure sebesar I,69 di SMPN I Martapura, I,38 di SMPN I Gambut, dan I,48 di sekolah-sekolah berkurikulum 2013 dan akreditasi A (Kurikulum 2013). Soal tersebut merupakan soal yang sedang dan berkualitas baik (Anggraini \& Suyata, 2014 dan Prilantari 2007). Cuplikan soal yang sulit dapat dilihat pada gambar 3. 


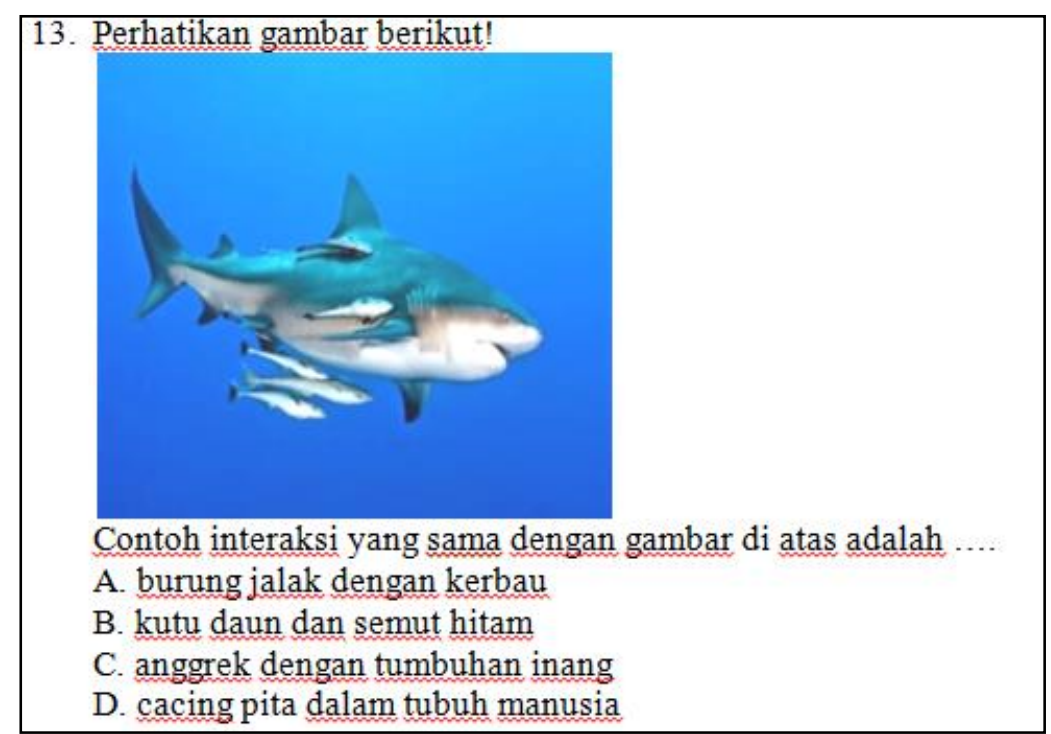

Gambar 3. Soal Kategori Sulit pada Instrumen Penilaian Kognitif Kelas VII Kurikulum 2013 Sumber: Hasil Olah Data

Soal pada gambar 3 memiliki nilai item measure sebesar 2,8I di SMPN I Martapura, 2,09 di SMPN I Gambut, dan 2,33 di sekolah-sekolah berkurikulum 2013 dan akreditasi A (Kurikulum 20I3). Soal tersebut merupakan soal yang sulit dan berkualitas cukup baik (Anggraini \& Suyata, 2014 dan Prilantari 2007). Cuplikan soal yang tidak konsisten dapat dilihat pada gambar 4 .

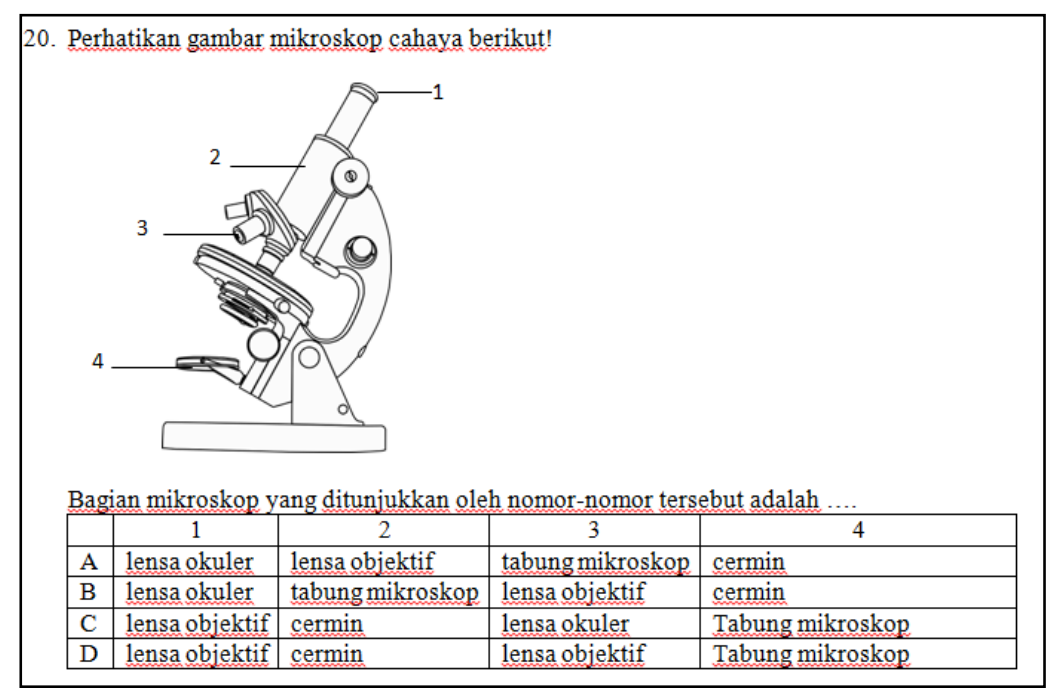

Gambar 4 Cuplikan Soal yang Tidak Konsisten pada Instrumen Penilaian Kognitif Kelas VII Kurikulum 2013 (Sumber: Hasil Olah Data)

Soal pada gambar 4 memiliki nilai item measure sebesar -2,83 di SMPN I Martapura, -I,73 di SMPN I Gambut, dan -I,90 di sekolah-sekolah berkurikulum 2013 dan akreditasi A (Kurikulum 2013). Soal tersebut merupakan soal yang sedang dan berkualitas baik kecuali di SMPN I Martapura merupakan soal yang mudah dan berkualitas cukup baik (Anggraini \& Suyata, 20I4 dan Prilantari 2007).

Butir soal yang fit (kelas VIII) terdiri atas I soal yang mudah, 26 soal yang sedang, dan I soal yang sulit. Ditemukan soal berprilaku tidak konsisten yaitu butir soal nomor 4, 5, 6, 9, I I, I2, dan 44. Cuplikan soal yang mudah dapat dilihat pada Gambar 5. 


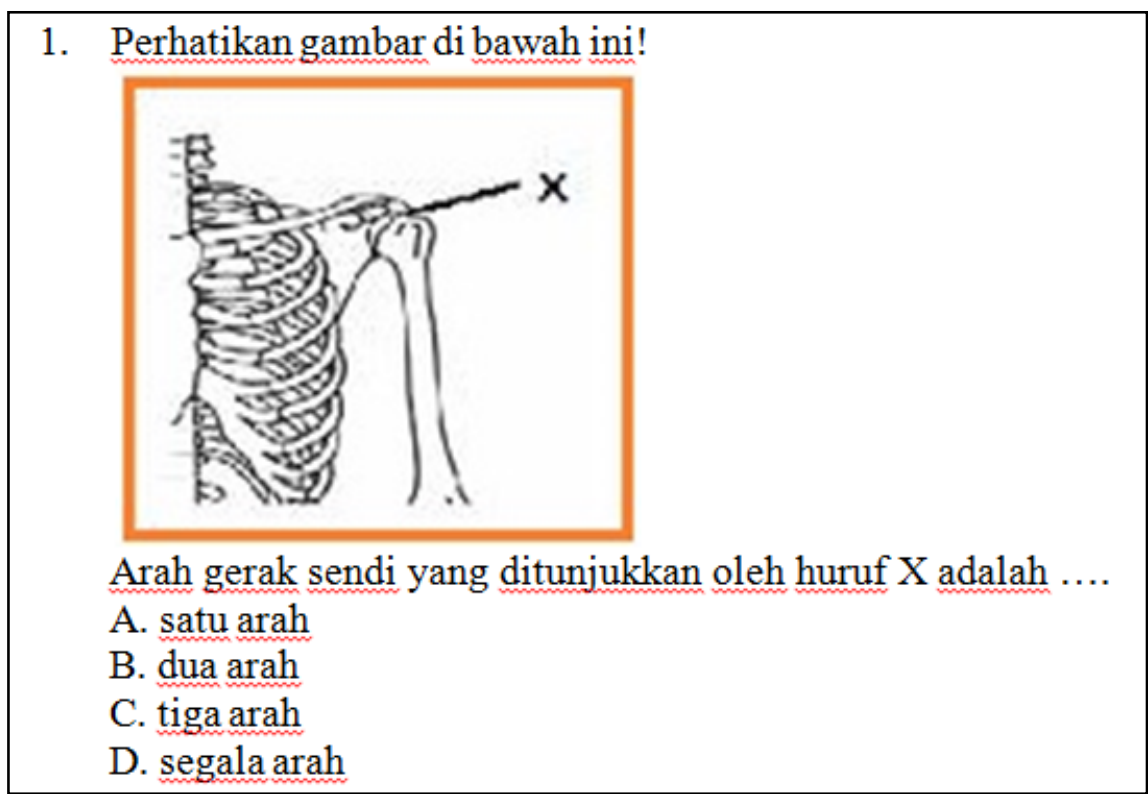

Gambar 5 Cuplikan Soal Kategori Mudah pada Instrumen Penilaian Kognitif Kelas VIII Kurikulum 2013 (Sumber: Hasil Olah Data)

Soal pada gambar 5 memiliki nilai item measure sebesar -2,43 di SMPN I Martapura, -3,96 di SMPN I Gambut, dan -3,I4 di sekolah-sekolah berkurikulum 2013 dan akreditasi A (Kurikulum 20I3). Soal tersebut merupakan soal yang mudah dan berkualitas cukup baik (Anggraini \& Suyata, 2014 dan Prilantari 2007). Cuplikan soal yang sedang dapat dilihat pada gambar 6

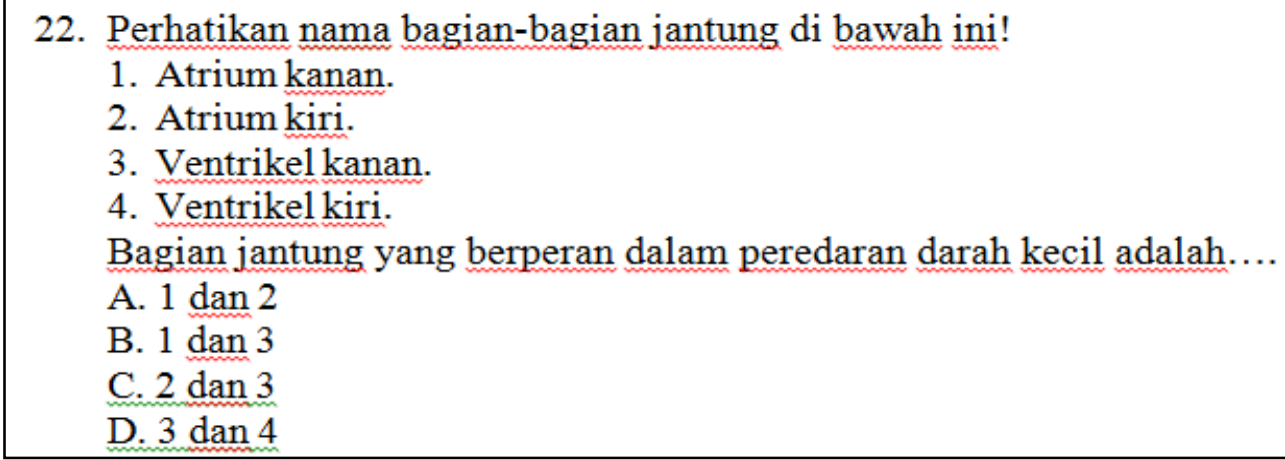

Gambar 6. Cuplikan Soal Kategori Sedang pada Instrumen Penilaian Kognitif Kelas VIII Kurikulum 2013 (Sumber: Hasil Olah Data)

Soal pada gambar 6 memiliki nilai item measure sebesar -0,82 di SMPN I Martapura, -0,09 di SMPN I Gambut, dan -0,84 di sekolah-sekolah berkurikulum 2013 dan akreditasi A (Kurikulum 2013). Soal tersebut merupakan soal yang sedang dan berkualitas baik (Anggraini \& Suyata, 2014 dan Prilantari 2007). Cuplikan soal yang sulit dapat dilihat pada gambar 7 . 
16. Dian berjalan di kebun belakang rumahnya tanpa alas kaki. Tanpa sengaja Dian menginjak paku yang terlindungi oleh rumput. Dian terkejut dan langsung mengangkat kaki sambil berteriak meminta pertolongan. Faktor yang paling berpengaruh pada gerakan di atas adalah ....
A. otak besar dan kecil
B. tulang, otot, dan sendi
C. kaki, tangan, dan mulut
D. sumsum tulang belakang

Gambar 7. Cuplikan Soal Kategori Sulit pada Instrumen Penilaian Kognitif Kelas VIII Kurikulum 2013 (Sumber: Hasil Olah Data)

Soal pada gambar 7 memiliki nilai item measure sebesar 4,32 di SMPN I Martapura, 6,62 di SMPN I Gambut, dan 4,9I di sekolah-sekolah berkurikulum 2013 dan akreditasi A (Kurikulum 20I3). Soal tersebut merupakan soal yang sulit dan berkualitas cukup baik (Anggraini \& Suyata, 2014 dan Prilantari 2007). Cuplikan soal yang tidak konsisten dapat dilihat pada gambar 8.

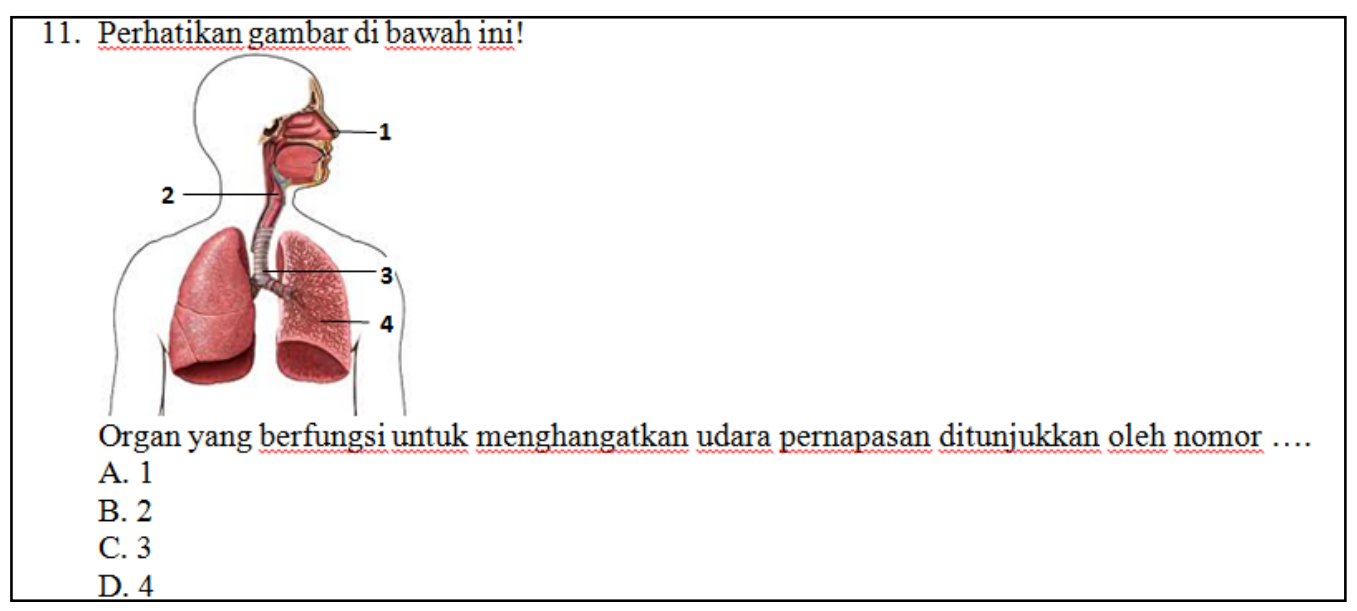

Gambar 8. Cuplikan Soal Kategori Sedang yang Tidak Konsisten pada Instrumen Penilaian Kognitif Kelas VIII Kurikulum 2013 (Sumber: Hasil Olah Data)

Soal pada gambar 8 memiliki nilai item measure sebesar 0,9I di SMPN I Martapura dan I,75 di sekolahsekolah berkurikulum 2013 dan akreditasi A (Kurikulum 2013), namun bernilai 6,62 di SMPN I Gambut. Soal tersebut merupakan soal sedang yang berkualitas baik namun sulit bagi peserta tes di SMPN I Gambut (Anggraini \& Suyata, 2014 dan Prilantari 2007)

Butir soal yang fit (kelas IX) terdiri atas I soal yang mudah, 6 soal yang sedang, dan tidak ada soal yang sulit. Ditemukan soal yang berprilaku tidak konsisten yaitu soal nomor I, 2, I7, dan 2I. Cuplikan soal yang mudah dapat dilihat pada gambar 9.

9. Penyakit AIDS dapat dicegah dengan ....
A. menghindari seks bebas
B. rajin melakukan donor darah
C. menggunakan alat kontrasepsi
D. memakai jarum tindik bersama

Gambar 9. Cuplikan Soal Kategori Mudah pada Instrumen Penilaian Kognitif Kelas IX Kurikulum 2013 (Sumber: Hasil Olah Data) 
Soal pada gambar 9 memiliki nilai item measure sebesar -2,75 di SMPN I Martapura, -3,48 di SMPN I Gambut, dan -2,77 di sekolah-sekolah berkurikulum 2013 dan akreditasi A (Kurikulum 2013. Soal tersebut merupakan soal mudah yang berkualitas cukup baik (Anggraini \& Suyata, 2014 dan Prilantari 2007). Cuplikan soal yang sedang dapat dilihat pada gambar IO.

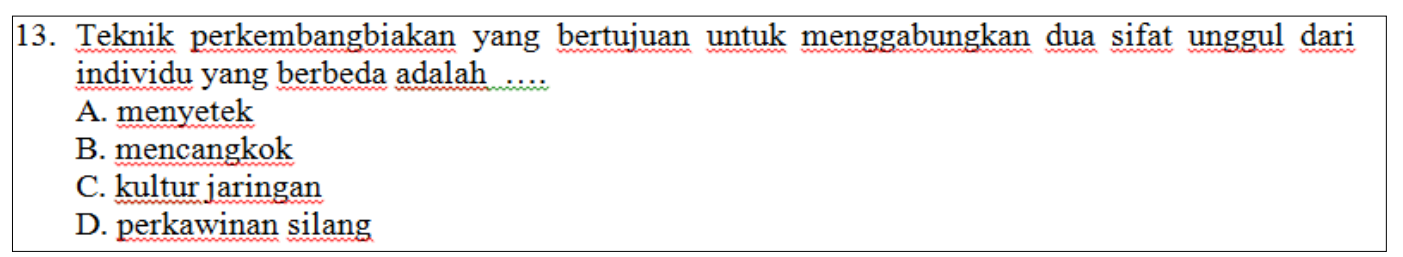

Gambar I0. Cuplikan Soal Kategori Sedang pada Instrumen Penilaian Kognitif Kelas IX Kurikulum 2013 (Sumber: Hasil Olah Data)

Soal pada gambar I0 memiliki nilai item measure sebesar I,43 di SMPN I Martapura, 0,I I di SMPN I Gambut, dan 0,56 di sekolah-sekolah berkurikulum 2013 dan akreditasi A (Kurikulum 2013. Soal tersebut merupakan soal sedang yang berkualitas baik (Anggraini \& Suyata, 2014 dan Prilantari 2007). Cuplikan soal yang tidak konsisten dapatdilihat pada gambar I I.

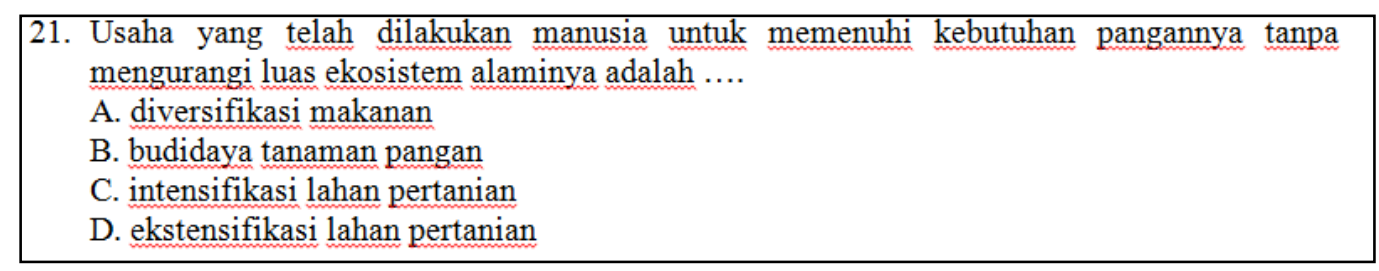

Gambar I I. Cuplikan Soal yang Tidak Ko nsisten pada Instrumen Penilaian Kognitif Kelas IX Kurikulum 2013 (Sumber: Hasil Olah Data)

Soal pada gambar II memiliki nilai item measure sebesar 2,43 di SMPN I Martapura, 2,3 I di SMPN I Gambut, dan I,84 di sekolah-sekolah berkurikulum 2013 dan akreditasi A (Kurikulum 2013. Soal tersebut merupakan soal sulit yang berkualitas cukup baik namun merupakan soal yang sedang dan berkualitas baik pada sekolah-sekolah berkurikulum 2013 dan sekolah akreditasi A (kurikulum 2013) (Anggraini \& Suyata, 2014 dan Prilantari 2007).

\section{Butir Soal yang Fit pada Instrumen Penilaian Kognitif Mata Pelajaran IPA SMP yang Mengimplementasikan KTSP}

Butir soal yang fit (kelas VII) terdiri atas 3 butir soal yang sedang yaitu soal nomor 8, 2I, dan 22. Ditemukan 2 butir soal berkategori sedang yang tidak konsisten dan I butir soal mudah yang tidak konsisten. Cuplikan soal berkategori sedang dapat dilihat pada gambar 12 .

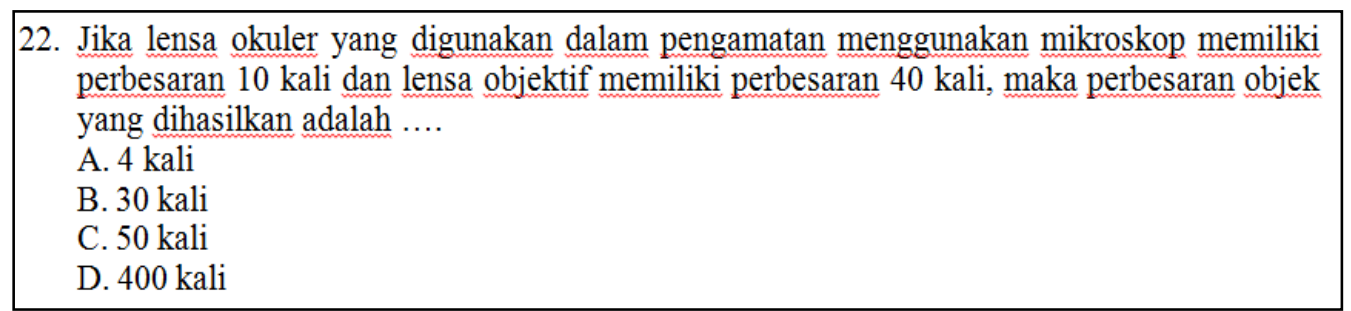

Gambar I2. Cuplikan Soal Sedang pada Instrumen Penilaian Kognitif Kelas VII KTSP (Sumber: Hasil Olah Data) 
Soal pada gambar I2 memiliki nilai item measure sebesar I,23 di SMPN 3 Martapura dan sekolah akreditasi A, I,20 di SMPN I Pengaron, I,30 di SMPN 2 Sungai Pinang dan sekolah yang belum akreditasi, I,2I di SMP Darussalam, 0,89 di sekolah-sekolah berkurikulum KTSP, dan I,08 di sekolah akreditasi B. Soal tersebut merupakan soal sedang yang berkualitas baik (Anggraini \& Suyata, 2014 dan Prilantari 2007). Cuplikan soal berkategori mudah yang tidak konsisten dapat dilihat pada gambar I3.

4. Makhluk hidup memiliki kemampuan untuk menyesuaikan diri dengan lingkungan yang
disebut .....
A. ekskresi
B. respirasi
C. adaptasi
D. reproduksi

Gambar I3. Cuplikan Soal Mudah yang Tidak Konsisten pada Instrumen Penilaian Kognitif Kelas VII KTSP (Sumber: Hasil Olah Data)

Soal pada gambar I3 memiliki nilai item measure sebesar -3,58 di SMPN 3 Martapura dan sekolah akreditasi A, -4,56 di SMPN I Pengaron, -I,74 di SMPN 2 Sungai Pinang dan sekolah yang belum akreditasi, -2,52 di SMP Darussalam, -2,63 di sekolah-sekolah berkurikulum KTSP, dan -3,I7 di sekolah akreditasi B. Soal tersebut merupakan soal mudah yang berkualitas cukup baik namun merupakan soal berkategori sedang dan berkualitas baik di sekolah SMPN 2 Sungai Pinang dan belum akreditasi (Anggraini \& Suyata, 2014 dan Prilantari 2007). Cuplikan soal berkategori sedang yang tidak konsisten dapat dilihat pada gambar I4.

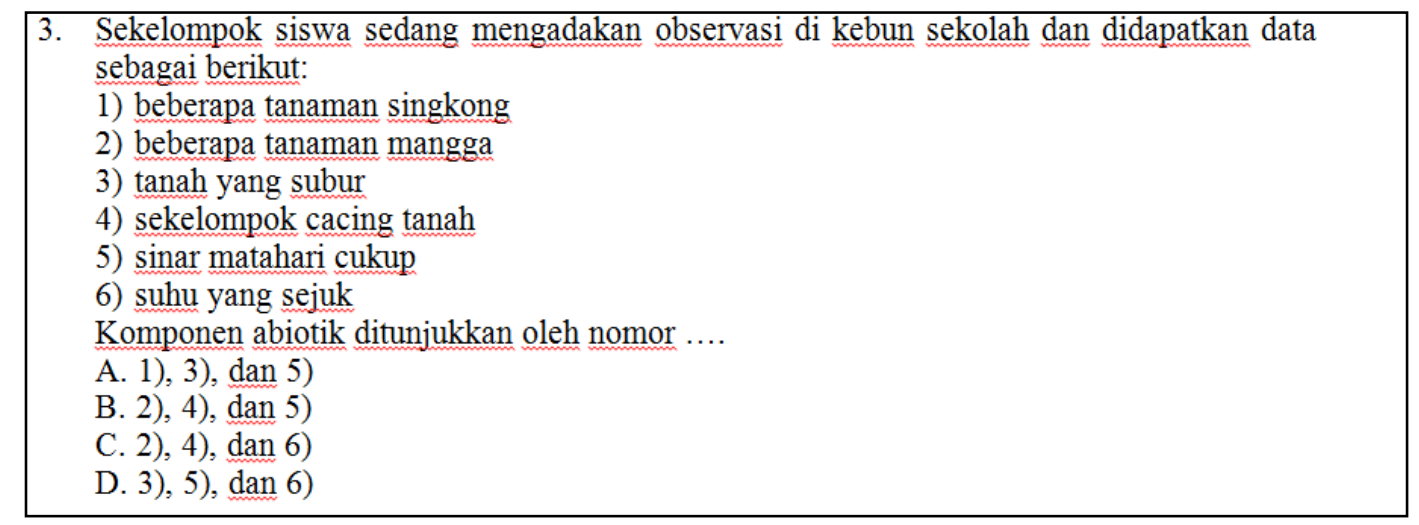

Gambar I4. Cuplikan Soal Sedang yang Tidak Konsisten pada Instrumen Penilaian Kognitif Kelas VII KTSP (Sumber: Hasil Olah Data)

Soal pada gambar I4 memiliki nilai item measure sebesar I,72 di SMPN 3 Martapura dan sekolah akreditasi A, -0,88 di SMPN I Pengaron, -3,48 di SMPN 2 Sungai Pinang dan sekolah yang belum akreditasi, 0,08 di SMP Darussalam, -0,70 di sekolah-sekolah berkurikulum KTSP, dan -3,34 di sekolah akreditasi B. Soal tersebut merupakan soal sedang yang berkualitas baik namun merupakan soal berkategori mudah dan berkualitas cukup baik di SMPN 2 Sungai Pinang, sekolah belum akreditasi, dan sekolah akreditasi B (Anggraini \& Suyata, 2014 dan Prilantari 2007).

Butir soal yang fit (kelas VIII) terdiri atas I butir soal yang sedang yaitu soal nomor 34. Terdapat 3 butir soal berkategori sedang yang tidak konsisten yaitu butir soal nomor I3, I4, dan I8. Cuplikan soal berkategori sedang dapat dilihat pada gambar 15 


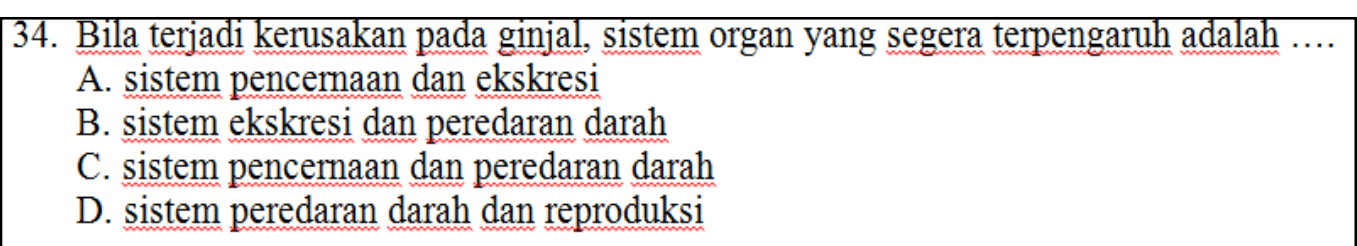

Gambar I5. Cuplikan Soal Sedang pada Instrumen Penilaian Kognitif Kelas VIII KTSP (Sumber: Hasil Olah Data)

Soal pada gambar I5 memiliki nilai item measure sebesar I,80 di SMPN 3 Martapura dan sekolah akreditasi A, 0,6I di SMPN I Pengaron, I,44 di SMPN 2 Sungai Pinang dan sekolah yang belum akreditasi, -I,I4 di SMP Darussalam, 0,77 di sekolah-sekolah berkurikulum KTSP, dan -0,03 di sekolah akreditasi B. Soal tersebut merupakan soal sedang yang berkualitas baik (Anggraini \& Suyata, 2014 dan Prilantari 2007). Cuplikan soal berkategori sedang yang tidak konsisten dapat dilihat pada gambar 16.

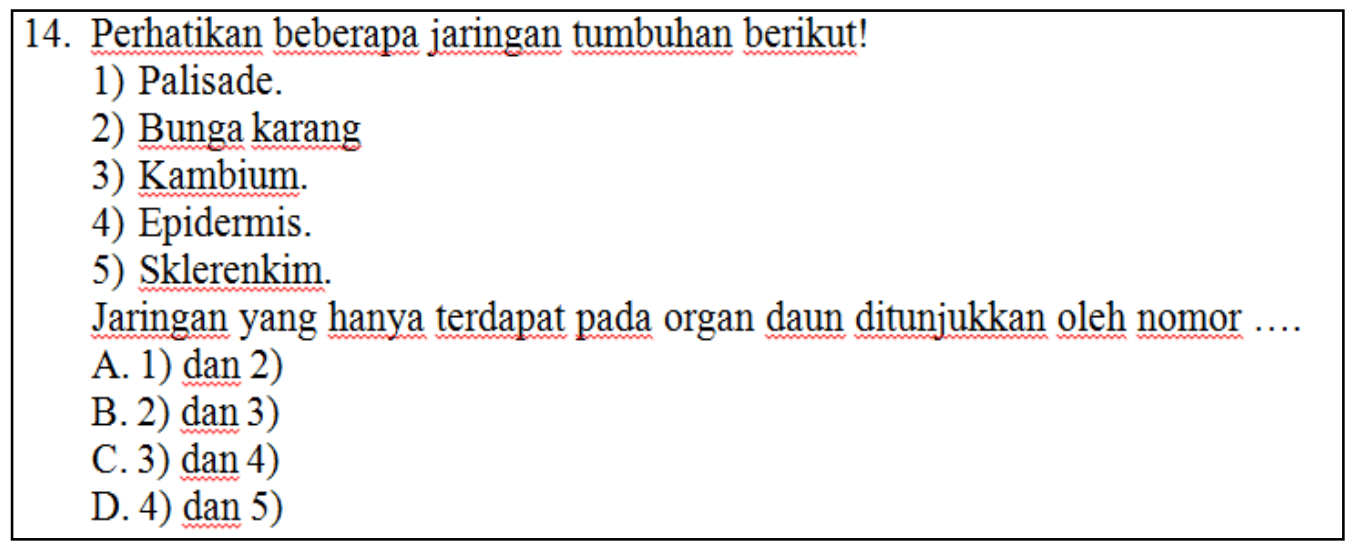

Gambar I6. Cuplikan Soal Sedang yang Tidak Konsisten pada Instrumen Penilaian Kognitif Kelas VIII KTSP (Sumber: Hasil Olah Data)

Soal pada gambar 16 memiliki nilai item measure sebesar 0,60 di SMPN 3 Martapura dan sekolah akreditasi A, 2,93 di SMPN I Pengaron, 0,34 di SMPN 2 Sungai Pinang dan sekolah yang belum akreditasi, -0,79 di SMP Darussalam, 0,77 di sekolah-sekolah berkurikulum KTSP, dan I,23 di sekolah akreditasi B. Soal tersebut merupakan soal sedang yang berkualitas baik namun soal yang sulit dan berkualitas cukup baik di SMPN I Pengaron (Anggraini \& Suyata, 20I4dan Prilantari 2007).

Butir soal yang fit pada instrumen penilaian kognitif mata pelajaran IPA SMP Kelas IX (KTSP) terdiri atas 3 butir soal berkategori sedang yang tidak konsisten yaitu butir soal nomor 8, I7, dan I8. Salah satu cuplikan soal tersebut dapat dilihat pada gambar I7.

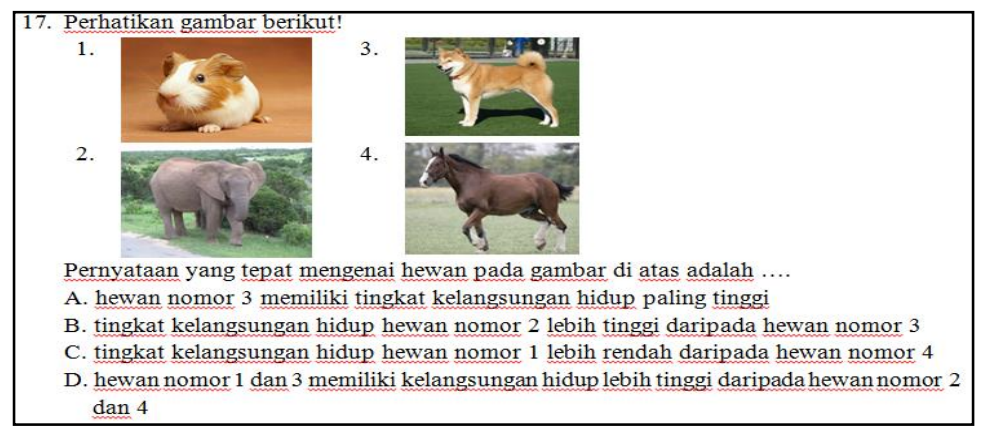

Gambar 17. Cuplikan Soal Sedang yang Tidak Konsisten pada Instrumen Penilaian Kognitif Kelas IX KTSP (Sumber: Hasil Olah Data) 
Soal pada Gambar 17 memiliki nilai item measure sebesar -3,92 di SMPN 3 Martapura dan sekolah akreditasi A, -I,70 di SMPN I Pengaron, -3,43 di SMPN 2 Sungai Pinang dan sekolah yang belum akreditasi, 0,92 di SMP Darussalam, -0,95 di sekolah-sekolah berkurikulum KTSP, dan -0,I6 di sekolah akreditasi B. Soal tersebut merupakan soal sedang yang berkualitas baik namun soal yang mudah dan berkualitas cukup baik di SMPN 3 Martapura dan SMPN I Pengaron (Anggraini \& Suyata, 2014 dan Prilantari 2007).

\section{Butir Soal yang Fit pada Instrumen Penilaian Kognitif Mata Pelajaran IPA SMP yang Mengimplementasikan Kurikulum Imbas 2013}

Butir soal yang fit (Kelas VII) terdiri atas 7 butir soal berkategori mudah, I6 butir soal berkategori sedang dan 2 butir soal berkategori sulit. Salah satu cuplikan soal tersebut dapat dilihat pada Gambar 18.

\section{Mudah}

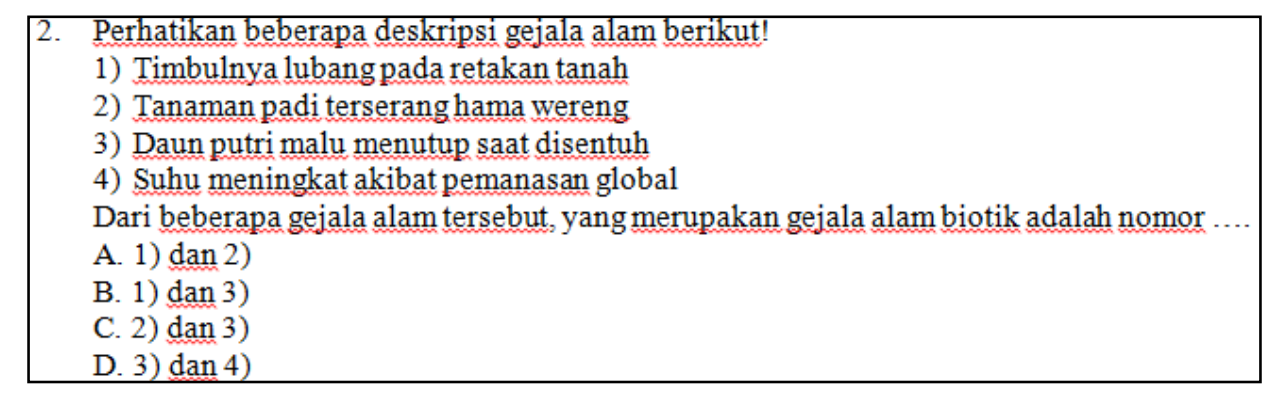

\section{Sedang}

6. Perhatikan gambar percobaan di bawah ini!

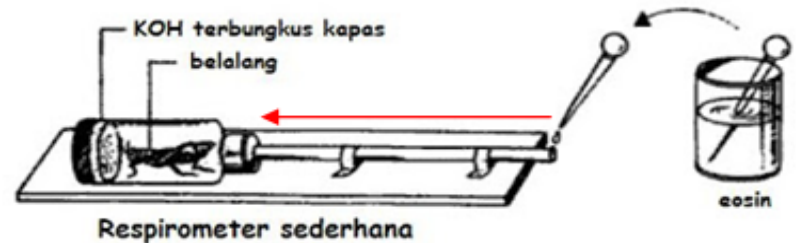

Percobaan pada gambar di atas menunjukkan bahwa makhluk hidup ....
A. memerlukan makan
B. mengeluarkan zat sisa
C. peka terhadap rangsang
D. melakukan pernapasan

Sulit

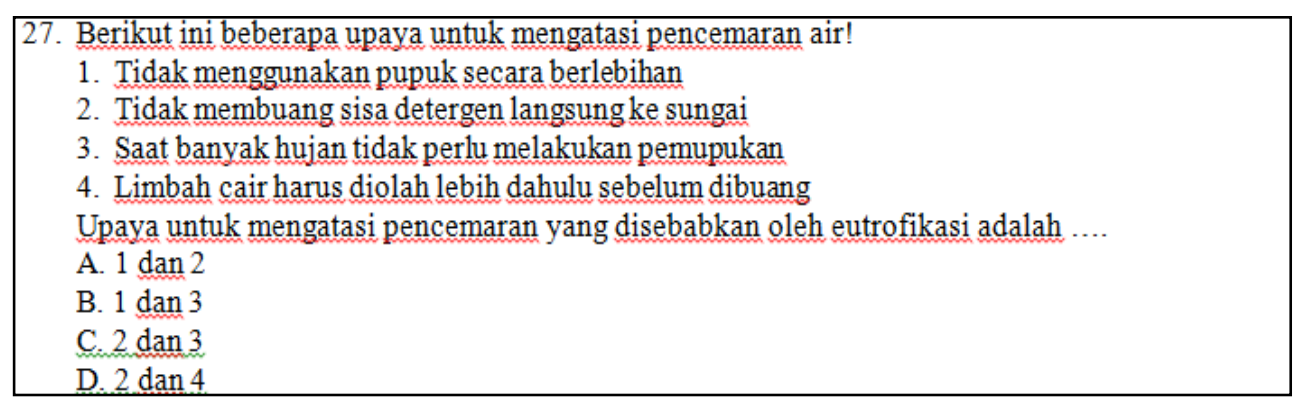

Gambar I8. Cuplikan Soal Mudah, Sedang, dan Sulit pada Instrumen Penilaian Kognitif Kelas VII Kurikulum Imbas 2013 (Sumber: Hasil Olah Data) 
Soal pada gambar 18 memiliki nilai item measure secara berurutan sebesar -2,46, 0,35 dan 6,08. Hal ini menunjukkan bahwa soal tersebut adalah mudah, sedang, dan sulit. Butir soal kategori sedang memiliki kualitas baik sedangkan soal yang mudah dan sulit berkualitas cukup baik (Anggraini \& Suyata, 2014 dan Prilantari 2007).

Butir soal yang fit pada instrumen penilaian kognitif mata pelajaran IPA SMP Kelas VIII (Kurikulum Imbas 2013) terdiri atas I butir soal berkategori mudah dan 23 butir soal berkategori sedang. Salah satu cuplikan soal tersebut dapat dilihat pada gambar I9.

\section{Mudah}

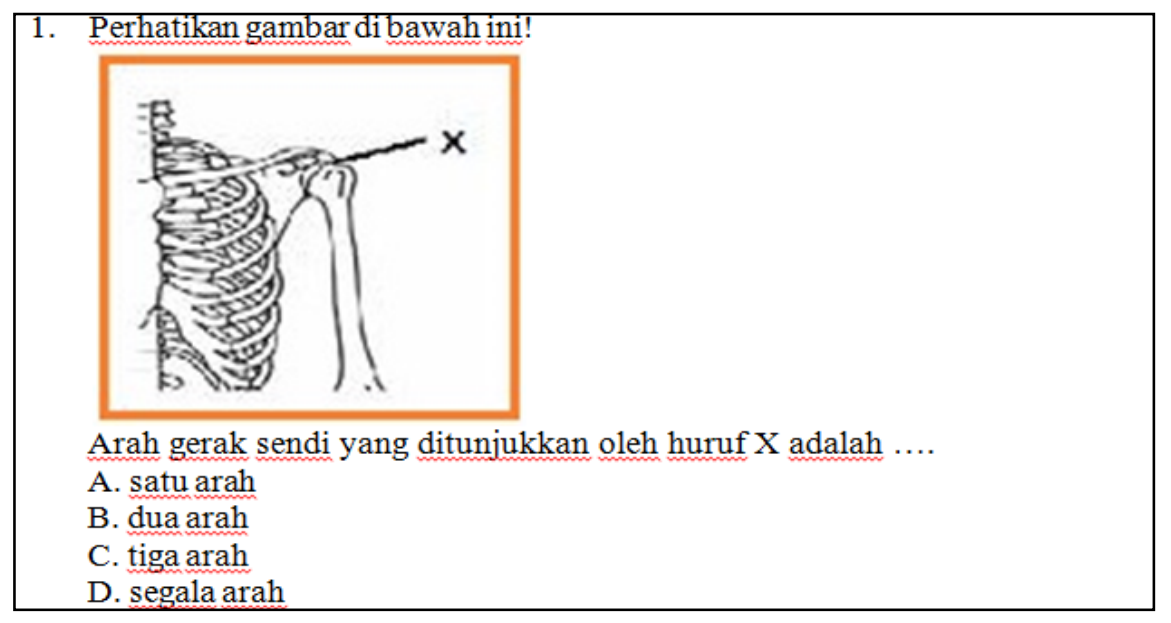

\section{Sedang}

15. Percobaan yang membuktikan adanya jaringan pengangkut pada tumbuhan adalah ....

A. merendam wortel yang telah dilubangi di bagian tengahnya di dalam air

B. membungkus daun keladi dengan kantong plastik yang diikat rapat.

C. menggantungkan kecambah di dalam tabung yang berisi air kapur dan ditutup rapat.

D. merendam batang tumbuhan pacar air berdaun di dalam larutan berwarna yang ditutup rapat.

Gambar 19. Cuplikan Soal Mudah dan Sedang pada Instrumen Penilaian Kognitif Kelas VIII Kurikulum Imbas 2013 (Sumber: Hasil Olah Data)

Soal pada gambar 19 memiliki nilai item measure secara berurutan sebesar -2,63 dan 0,70. Hal ini menunjukkan bahwa soal tersebut adalah soal yang mudah dan sedang. Butir soal kategori sedang memiliki kualitas baik sedangkan soal yang mudah berkualitas cukup baik (Anggraini \& Suyata, 2014 dan Prilantari 2007).

Butir soal yang fit (kelas IX) terdiri atas 6 butir soal berkategori mudah, I4 butir soal berkategori sedang, dan I butir soal dengan kategori sulit. Salah satu cuplikan soal tersebut dapat dilihat pada Gambar 20. 
Sulit

3. Perhatikan gambar percobaan di bawah ini!

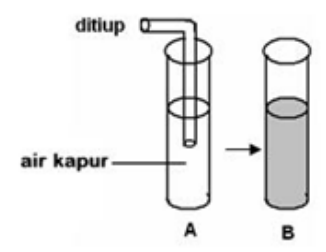

Percobaan di atas bertujuan untuk membuktikan fungsi paru-paru mengeluarkan....
A. $\mathrm{O}_{2}$
B. $\mathrm{CO}_{2}$
C. $\mathrm{H}_{2} \mathrm{O}$
D. $\mathrm{H}_{2} \mathrm{O}_{2}$

13. Seorang pasien di rumah sakit memiliki ciri-ciri timbul panas di kemaluan, ngilu pada otot, dan timbul gelembung seperti cacar. Pasien tersebut diperkirakan terkena penyakit ....
A. sifilis
B. herpes
C. klamidia
D. HIV/AIDS

26. Pengaruh kepadatan populasi manusia terhadap lingkungan adalah ....
A. peningkatan jumlah penduduk tidak mempengaruhi pencemaran lingkungan
B. kasus pencemaran semakin meningkat seiring peningkatan jumlah penduduk
C. jumlah penduduk tidak berpengaruh terhadap kondisi di lingkungan sekitar
D. peningkatan jumlah penduduk mengakibatkan peningkatan produksi sampah

Gambar 20. Cuplikan Soal Mudah, Sedang dan Sulit pada Instrumen Penilaian Kognitif Kelas IX Kurikulum Imbas 2013 (Sumber: Hasil Olah Data)

Soal pada gambar 20 memiliki nilai item measure secara berurutan sebesar -3,25, -I,79 dan 2,25. Hal ini menunjukkan bahwa soal tersebut adalah soal yang mudah, sedang, dan sulit. Butir soal kategori sedang memiliki kualitas baik sedangkan soal yang mudah dan sulit berkualitas cukup baik (Anggraini \& Suyata, 20I4 dan Prilantari 2007).

\section{Penutup}

Berdasarkan hasil penelitian dan pembahasan, simpulan dari penelitian yang dilakukan adalah butir soal yang fit pada instrumen penilaian kognitif mata pelajaran IPA SMP hasil pengembangan adalah 59,80\% dari jumlah soal yang diujikan pada sekolah sekolah yang menggunakan kurikulum 2013, terdapat 74,83\% dari soal yang diujikan pada sekolah yang menggunakan Kurikulum Imbas 20I3, dan I2,74\% dari soal yang diujikan pada sekolah-sekolah yang menggunakan kurikulum KTSP. Soal soal yang fit tersebut terdiri atas soal yang mudah, sedang, dan sulit.

\section{Daftar Pustaka}

Anggraini, D dan Suyata, P. 20I4. Karakteristik Soal UASBN Mata Pelajaran Bahasa Indonesia di Daerah Istimewa Yogyakarta pada Tahun Pelajaran 2008/2009. Jurnal Prima Edukasia 2 (I): 57-65.

Ariffin, S.H; R. Idris; N.M. Ishak. 20I0. Differential Item Functioning in Malaysian Generic Skills Instrument (MyGSI). Jurnal Pendidikan Malaysia 35 (I): I-IO. 
Chiang, W.W. 20I5. Ninth Grade Student' self assessment in science : A Rasch Analysis Approach. Procidia Social and Behavioral Science 175: 200-2I0.

Golia, S. 2010. The Assessment of DIF on RASCH Measures With an Application to Job Satisfaction. Electronic Journal of Applied Statistical Analysis: Decision Support Systems and Services Evaluation I (I): I6-25.

Mamu, H.D. 20I4. Pengaruh Strategi Pembelajaran, Kemampuan Akademik dan Interaksinya terhadap Keterampilan Berpikir Kritis dan Hasil Belajar Kognitif IPA Biologi. Jurnal Pendidikan Sains 2 (I): III.

Mardapi, D; Kumaidi; Kartowagiran,B. 20II. Pengembangan Instrumen Pengukur Hasil Belajar Nirbias dan Terskala Baku. Jurnal Penelitian dan Evaluasi PendidikanI5(2): 326-34I.

Mendiknas. 2007. Permendiknas No.20 Tahun 2007 tentang Standar Penilaian Pendidikan (online)

Hidayati, I.F dan D. Rosana. 20I3. Penerapan Rasch Model Berbasis IRT dalam Analisis Soal UAS Fisika SMA Kelas XI Menggunakan Program Bigsteps sebagai Acuan Pembuatan Perangkat Soal yang Berkualitas. Jurnal Universitas Negeri Yogyakarta 2 (5): I-7.

Prilantari, H. 2007. Pengembangan Bank Soal Keterampilan Proses IPA (Biologi) Kelas X Tingkat Madrasah Aliyah. Jurnal Penelitian dan Evaluasi Pendidikan 2(I0):223-234.

Sukor, N.S; K.Osman; T.M.T. Soh. 2013. Chemistry Test Item Development: Assesing Conceptual Understanding among Malaysian Students. Asian Social Science 9 (I6): I26-I32.

Wardhani, D.F., Suratno, Putra, A.P. 2017. Characteristics of School Examination Test Of Biology Subject in Banjar Regency in The Academic Year of 2014/2015. Abstract. Programme Book The $5^{\text {th }}$ SEA-DR International Conference 20I7. Dephartement of Mathematics and Natural Science Education Universitas Lambung Mangkurat, Banjarmasin. 